\title{
Особливості хірургічного лікування паціентів із синдромом підключично-хребтового обкрадання
}

\begin{abstract}
Мета роботи: систематизувати показання та розробити алгоритм відбору пацієнтів із синдромом підключично-хребтового обкрадання для хірургічного лікування.

Матеріали і методи. Проаналізовано результати хірургічного лікування 19 хворих із синдромом підключично-хребтового обкрадання (СПХО). Всіх хворих було прооперовано тільки після вичерпаних можливостей ендоваскулярної реваскуляризації. Артеріальну реконструкцію виконували під загальним знеболюванням в умовах інтраопераційного нейромоніторингу за допомогою транскраніальної оксиметрії. При виборі артеріальної реконструкції надавали перевагу транспозиції підключичної артерії до загальної сонної артерії (9 пацієнтів, 47,4%). Окрім транспозиції, 5 пацієнтам (26,3 \%) виконували сонно-підключичне шунтування, 4 пацієнтам (21,1 \%) сонно-сонне шунтування, одному пацієнту (5,3%) протезування брахіоцефального стовбура. Результати досліджень та їх обговорення. В обстежуваній групі переважали пацієнти з I (36,8\%) та II (31,6\%) ступенем ішемії верхньої кінцівки. До групи з І ступенем входили 4 пацієнти (21,1%), у яких запланована імплантація стентграфту із закриттям гирла лівої ЗагСА. IV ступінь ішемії верхньої кінцівки спостерігали у двох пацієнтів (10,5 \%). У ранньому післяопераційному періоді в одного пацієнта (5,3%) після сонно-сонного шунтування розвинувся ішемічний інсульт. Один хворий помер (5,3 \%) - після сонно-сонного шунтування та імплантації стентграфту. Тактика лікування хворих із СПХО залежить не тільки від виду СПХО, стану прохідності гомо- та контрлатеральних судин, які кровопостачають головний мозок, але і від типу порушення мозкового кровообігу.
\end{abstract}

Ключові слова: стеноз сонних артерій; синдром підключично-хребтового обкрадання; хронічна ішемія головного мозку; атеросклероз.

Постановка проблеми і аналіз останніх досліджень та публікацій. Синдром підключичнохребтового обкрадання (СПХО) найчастіше виникає у разі атеросклеротичного стенозу або оклюзії початкового відділу підключичної артерії $[1,2]$. Клінічно проявляється втратою свідомості у поєднанні з іншими симптомами вертебрально-базилярної недостатності, що часто виникають під час енергійного фізичного навантаження ураженої верхньої кінцівки («рука-провокатор») [3, 4]. Частіше steal-синдром спостерігають у хворих із атеросклеротичним ураженням зліва, хоча цей синдром може бути і двобічним $[1,5]$.

Об'єктивним підтвердженням наявності stealсиндрому є результати рентгеноконтрастної ангіографії, під час якої при введенні контрастної речовини в контрлатеральну підключичну артерію уражена заповнюється через систему хребтових артерій $[2,6]$. При виборі методу лікування синдрому підключично-хребтового обкрадання на сьогодні більшість авторів віддає перевагу рентген-ендоваскулярним методам реконструкції підключичної артерії (ПКА) [7]. Водночас є чимало прибічників відкритих операційних втручань при СПХО (транспозиція ПКА в загальну сонну артерію (ЗагСА)), сонно-підключичне шунтування [4, 5]. Ще однією проблемою атеросклерозу є ураження декількох екстракраніальних судинних басей- нів, що може впливати на послідовність та тактику лікування [8]. Враховуючи розбіжність поглядів на підхід до лікування СПХО доцільно систематизувати алгоритм лікування даної патології.

Мета роботи: систематизувати показання та розробити алгоритм відбору пацієнтів із синдромом підключично-хребтового обкрадання для хірургічного лікування.

Матеріали і методи. За період із 2010 до 2016 р. у клініці судинної хірургії, VÚSCH, Koшице, Словацька Республіка 19 пацієнтам виконано хірургічне лікування синдрому підключичнохребтового обкрадання.

Показанням до виконання хірургічного лікування були:

1. Пацієнти із симптоматичним субтотальним стенозом/оклюзією I сегмента ПкА при вичерпаних можливостях ендоваскулярних втручань.

2. Хворі з аневризматичним ураженням або розшаруванням дуги аорти, у яких заплановано імплантацію стентграфту із закриттям гирла лівої ЗагСА (загальна сонна артерія).

На етапі об'єктивного обстеження хворих при визначенні ступеня ішемії верхньої кінцівки використовували таку класифікацію:

I ступінь - стадія стійкої компенсації кровотоку; 
II ступінь - стадія відносної компенсації кровотоку (ознаки ішемії кінцівки виявляють при фізичному навантаженні);

III ступінь - стадія виснаження компенсації (ознаки ішемії кінцівки присутні у стані спокою);

IV ступінь - стадія декомпенсації або стадія виразково-некротичних змін.

Розподіл пацієнтів за ступенем ішемії верхньої кінцівки представлено в таблиці 1.

Таблиця 1. Ступінь ішемії верхньої кінцівки в обстежуваних пацієнтів

\begin{tabular}{||c|c|c||}
\hline Ступінь ішемії & Кількість & $\%$ \\
\hline I & 4 & 21,1 \\
\hline II & 7 & 36,8 \\
\hline III & 6 & 31,6 \\
\hline IV & 2 & 10,5 \\
\hline
\end{tabular}

3 метою визначення гемодинамічного обкрадання кровопостачання головного мозку та формування шляхів компенсації кровопостачання у передопераційний період всім пацієнтам виконували дуплексне сканування екстракраніальних артерій та інтракраніальний доплер.

3 метою об’єктивної візуалізації рівня стенозу та виявлення мультисегментарного ураження екстракраніальних артерій всім хворим виконували діагностичну ангіографію.

Вибір методу та техніки артеріальної реконструкції залежав від довжини атеросклеротичного стенозу, наявності або відсутності контрлатерального ураження, розвитку компенсаторних механізмів кровопостачання ураженого русла. 9 пацієнтам $(47,4$ \%) виконано транспозицію ПКА до ЗагСА. 4 пацієнтам (26,3 \%) виконано сонно-підключичне шунтування за допомогою синтетичного матеріалу. Даний вид операції виконували у зв'язку із поширенням атеросклеротичного ураження за межі I сегмента ПКА. В одного пацієнта внаслідок 80 \% стенозу в ділянці біфуркації ЗагСА виконали класичну ендартеректомію із заплатою. 4 хворим (21,1 \%) виконали сонно-сонне шунтування. Показанням до операції була потреба в реваскуляризації лівої ЗагСА у пацієнтів із симптоматичним атеросклеротичним ураженням дуги та низхідного відділу аорти, яким у плановому режимі виконали імплантацію стентграфту із прикриттям гирла лівої сонної артерії. Сонно-сонне шунтування виконували в плановому порядку перед імплантацією стентграфту. Одній пацієнтці (5,3 \%) виконано протезування брахіоцефального стовбура. У всіх пацієнтів операцію виконували під загальним знеболенням із інтраопераційною транскраніальною оксиметрією.
Результати досліджень та їх обговорення. Як видно з таблиці 1, в обстежуваній групі переважали пацієнти з I (36,8 \%) та II (31,6 \%) ступенем ішемії верхньої кінцівки. До І ступеня віднесено 4 пацієнтів (21,1 \%), у яких запланована імплантація стентграфту із закриттям гирла лівої ЗагСА. IV ступінь ішемії верхньої кінцівки спостерігали у двох пацієнтів (10,5 \%).

При оцінці гемодинамічних змін при II ступені хронічної ішемії верхніх кінцівок спостерігали гемодинамічно значиме зниження пікової систолічної швидкості в гомолатеральній хребтовій артерії; при III ступені хронічної ішемії верхніх кінцівок були умовно характерними гемодинамічно значиме компенсаторне підвищення пікової систолічної швидкості та об'ємної швидкості кровотоку в ЗовСА та зниження об'ємної швидкості кровотоку в гомолатеральній хребтовій артеpiї; IV ступінь хронічної ішемії верхніх кінцівок відрізнявся зростанням пікової систолічної швидкості у контрлатеральній хребтовій артерії, значимим падінням індексу резистентності у гомолатеральній хребтовій артерії, падінням індексу пульсативності на межі значимого у основній артерії та значимим падінням його у підключичній артерії, значимим компенсаторним підвищенням об'ємної швидкості кровотоку у контрлатеральній хребтовій артерії.

Механізми компенсації кровообігу оцінювали у 15 хворих (II-IV ступень ішемії при СПХО). У 4 пацієнтів з I ступенем ішемії не було доцільності проводити оцінку компенсаторних механізмів, позаяк ці хворі були без ознак хронічної ішемії.

У 9 (63,2 \%) пацієнтів виявлено екстракраніальний механізм компенсації, який забезпечувався у 5 пацієнтів (58,3 \%) потилично-хребтовим механізмом компенсації; у 3 пацієнтів (33,3 \%) щитоподібним механізмом; в одного хворого (8,3 \%) потилично-стовбуровим механізмом.

У 6 (36,8 \%) пацієнтів спостерігали інтракраніальний механізм компенсації, який забезпечувався у 4 пацієнтів хребтово-хребтовим механізмом та у 3 хворих церебро-базилярний гемодинамічним механізмом.

При оцінці післяопераційних ускладнень у ранньому післяопераційному періоді в одного пацієнта (5,3 \%) після соно-сонного шунтування розвинувся ішемічний інсульт. Помер один хворий $(5,3 \%)$ - після сонно-сонного шунтування та імплантації стентграфту.

До етіологічних факторів, які можуть призвести до виникнення синдрому підключичнохребтового обкрадання, відносять: а) облітеруючі захворювання екстракраніальних артерій (ате- 
росклероз, неспецифічний артеріїт); б) вторинні звуження гілок дуги аорти (розшаровуюча аневризма, атеросклеротичні та сифілітичні процеси); в) аномалії розвитку дуги аорти (патологічні деформації екстракраніальних артерій); г) екстравазальні фактори компресії артерій (пухлинні процеси) $[1,5,8]$.

Тактика лікування хворих із СПХО залежить не тільки від виду СПХО, стану прохідності гомо- та контрлатеральних судин, які кровопостачають головний мозок, супутнього атеросклеротичного ураження, але і від типу порушення мозкового кровообігу [9].

Стадія перебігу СПХО не $є$ визначальною для гемодинамічних змін, які не завжди пропорційно змінюються залежно від перебігу СПХО. Для більш точного встановлення гемодинамічних можливостей колатеральної компенсації необхідне врахування гемодинамічних змін у дистальному сегменті підключичної артерії, а також необхідне детальне вивчення церебральної гемодинаміки та врахування інтракраніальних механізмів компенсації; також слід враховувати параметри кровотоку в контрлатеральній хребтовій артерії $[4,7]$. У нашій групі хворих спостерігали статистично достовірний вплив басейну ЗовСА у формуванні гемодинамічних компенсаторних механізмів за рахунок колатералізації потоків та перерозподілу кровотоку у великі колатеральні артерії (потиличну та верхню щитоподібну артерії).

Для встановлення діагнозу та вибору методу лікування ми запропонували діагностичний алгоритм обстеження пацієнтів із СПХО у поєднанні із атеросклеротичним ураженням екстракраніальних артерій перед операційним втручанням:

1) клінічний огляд пацієнта для визначення ступеня судинно-мозкової недостатності за класифікацією Покровського А. В. (1979) та ступеня ішемії верхньої кінцівки; консультації суміжних спеціалістів;

2) провести УЗДС екстра- та інтракраніальних артерій з кольоровим картуванням кровотоку;

3) при малоінформаційних результатах визначення стану ПКА та інших артеріальних басейнів шиї при ультрасонографічному обстеженні застосовувати рентгеноконтрасну ангіографію;

4) KТ-ангіо або МРТ головного мозку хворим із ГПМК та ХПМК із тяжким неврологічним дефіцитом.

Завданням хірургічного лікування при синдромі підключично-хребтового обкрадання у пацієнтів з хронічним порушенням мозкового кровообігу є:
1) зменшення симптомів порушення мозкового кровообігу у вертебро-базилярному басейні;

2) покращення показників кровотоку в дистальних відділах кінцівок, поліпшити функції в/к і загального стану хворого;

3) покращення якості життя хворого, зниження ризику повторних порушень мозкового кровообігу $[3,6]$.

Ми виконували реваскуляризацію тільки у симптоматичних пацієнтів.

Ендоваскулярні втручання мають бути операціями вибору, оскільки вони дають можливість маніпулювати одномоментно в певній послідовності на декількох артеріальних басейнах, малотравматичні, скорочують термін перебування пацієнтів в стаціонарі [4]. У випадку вичерпаних можливостей ендоваскулярної реваскуляризації операцією вибору є хірургічне лікування [7]. Серед відкритих операційних втручань виконують транспозицію підключичної артерії в іпсілатеральну загальну сонну артерію або сонно-підключичне шунтування. Ми надавали перевагу транспозиції ПКА (рис. 1, 2).

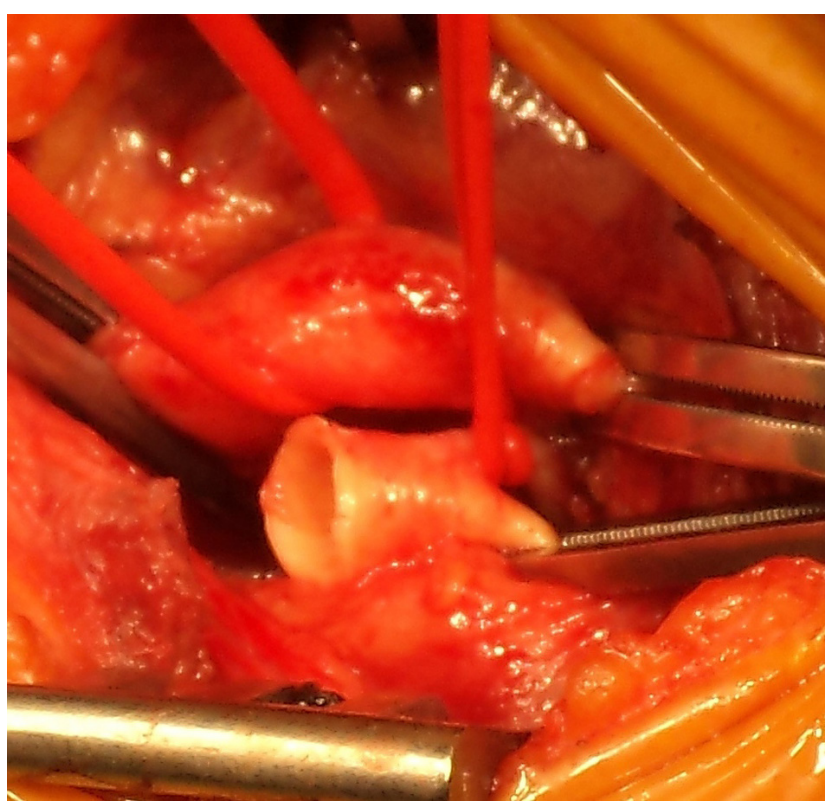

Рис. 1. Мобілізація ПКА.

Сонно-підключичне протезування виконували у випадку: а) технічної складності мобілізації першого сегмента підключичної артерії; б) поширення атеросклеротичної бляшки в напрямку хребтової артерії; в) вірогідності постреконструкційного натягу. Перевагою сонно-підключичного протезування $є$ технічна простота виконання. До недоліків слід віднести відсутність прямого кровотоку по підключичній артерії і необхідність використання синтетичного матеріалу [6, 8]. 


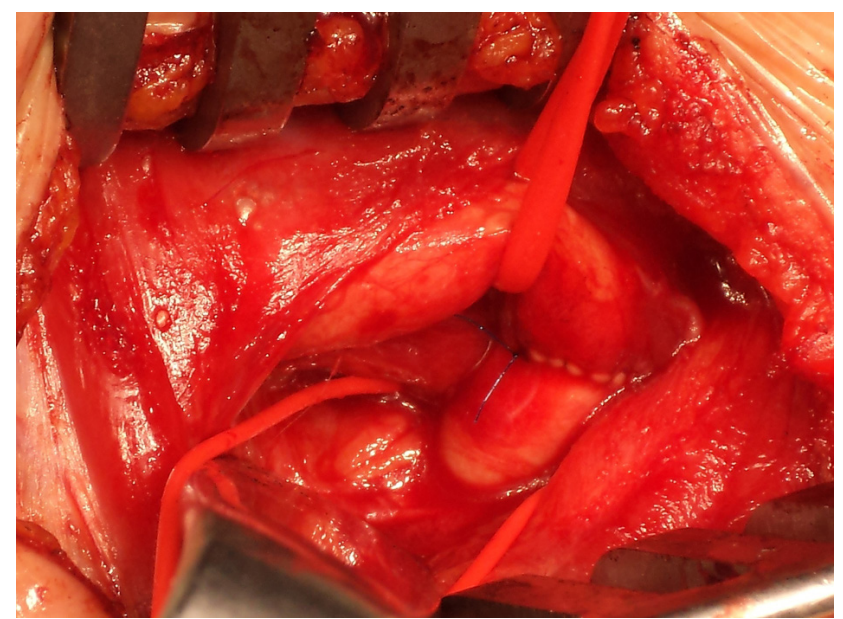

Рис. 2. Транспозиція ПКА в ЗагСА.

Сонно-сонне шунтування виконували при: а) потребі в реваскуляризації лівої ЗагСА у пацієнтів із хронічним розшаруванням або аневризмою дуги та низхідного відділу аорти, яким запланована імплантація стентграфту із прикриттям гирла лівої сонної артерії; б) наявності у хворого критичного стенозу або оклюзії загальної сонної артерії, I сегмента іпсілатеральної підключичної артерії. Ми виконували сонно-сонне шунтування з ретрофаренгіальним розташуванням протеза. Перевагою такої локалізації є рівніше положення та менша довжина протеза.

При оклюзії брахіоцефального стовбура виконують різноманітні способи обхідного шунтування синтетичними судинними протезами [9]. Ми виконували у однієї пацієнтки протезування брахіоцефального стовбура у зв'язку із оклюзією останнього (рис. 3). При цьому проксимальний анастомоз нашивали на висхідний відділ грудної аорти, а дистальні анастомози нашиті відповідно на ліву загальну сонну артерію та ліву підключичну артерію (рис. 4).

Висновки. 1. При синдромі підключичнохребтового обкрадання ендоваскулярне втручання має бути операцією вибору. У випадку вичерпаних можливостей ендоваскулярної реваскуляризації операцією вибору є хірургічне лікування.

\section{СПИСОК ЛІТЕРАТУРИ}

1. Синдром обкрадання при патології судин дуги аорти / В. І. Русин, В. В. Корсак, Є. С. Буцко [та. ін.]. - Ужгород : Карпати, 2011. - 208 с.

2. Хирургическое лечение пациентов с синдромом подключично-позвоночного обкрадывания / В. Б. Стародубцев, А. А. Карпенко, С. А. Альсов [ и др.] // Патология кровообращения и кардиохирургия. - 2009. - № 1. - С. 61-64.

3. Тактика хирургического лечения множественных атеросклеротических поражений ветвей дуги аорты / И. П. Никульников, А. В. Ратушнюк, П. А. Зайченко [и др.] // Ангиология

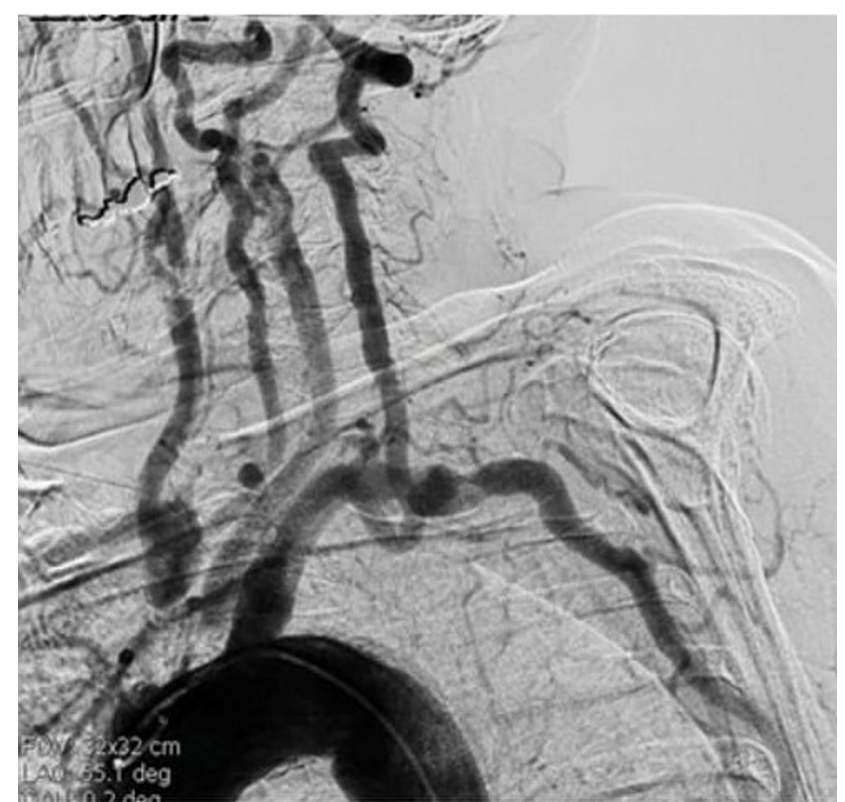

Рис. 3. Оклюзія брахіоцефального стовбура.

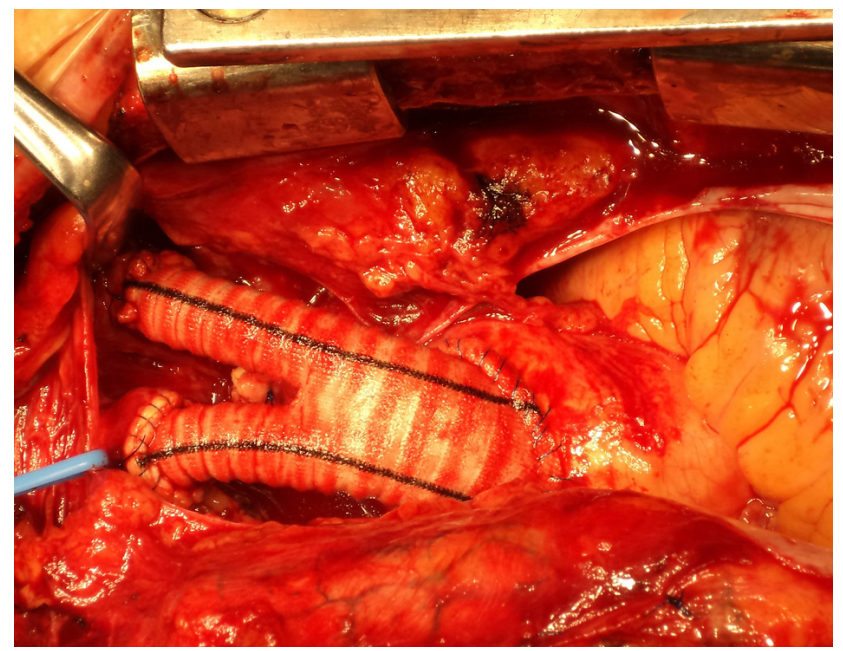

Рис. 4. Протезування брахіоцефального стовбура.

2. Артеріальна реконструкція при СПХО показана тільки у симптоматичних пацієнтів.

3. Ранні добрі та задовільні результати хірургічного лікування СПХО у представленій групі хворих становили 94,7\%.

и сосудистая хирургия. - М. - 2005. - № 2. - С. 221-222.

4. Можливості ендоваскулярного лікування атеросклеротичного ураження екстракраніальних артерій у гострий період ішемічного інсульту / В. І. Русин, В. В. Корсак, Є. С. Буцко, А. Г. Голяка // Науковий вісник Ужгородського університету. Серія “Медицина". - 2014. - Вип. 1(49). - С. 144-149.

5. Прогрессирующий церебральный атеросклероз: клинические, биохимические и морфологические аспекты / М. М. Танашян, О. В. Лагода Т. С. Гулевская [и др.] // Анналы клинической и экспериментальной неврологии. - 2013. - № 4. - С. 4-9. 
6. Sihotský V. Metodou prvej vol'by pri stenóze karotid je CEA / V. Sihotský // Cesk Slov Neurol. - 2016. - Vol. 79, 112(4). - P. 397-399. 7. Родин Ю. В. Оперативное лечение больных с патологией брахиоцефальных артерий сверхвысокого неврологического риска / Ю. В. Родин, В. А. Симонян, Д. Ш. Дюба // Хірургія України. - 2008. - Т. 2, № 4 (додаток). - С. 253-255.

\section{REFERENCES}

1. Rusyn, V.I., Korsak, V.V, Butsko, E.S., Levytskyi, A.V., \& Borsenko M.I. (2011). Syndrom obkradannia pry patolohii sudyn duhy aorty (The syndrome of stealing at the pathology of the vessels of the aortic arc). Uzhorod: Karpaty [in Ukrainian].

2. Starodubtsev, V.B., Karpenko, A.A., \& Alsov, S.A. (2009). Khirurgicheskoe lechenie patsientov s sindromom podkluchichno-pozvonocnogo obkradivania [Surgical treatment of patients with the syndrome of subclavian-vertebral stealing]. Patologia krovoobrashchenia i kardiokhirurgia - Pathology of blood circulation and cardiosurgery, (1), 61-64 [in Russian].

3. Nikulnikov, I.P., Ratushnuk, A.V., \& Zaychenko, P.A. (2005). Taktika khirurgiceskogo porazhenia vetvey dugi aorty [Tactics of surgical treatment of multiple atherosclerotic lesions of branches of the aortic arch]. Angiologia i sosudistaya kirurgia - Angiology and Vessel Surgery, (2), 221-222 [in Russian].

4. Rusyn, V.I., Korsak, V.V, Butsko, Te.S., \& Holiaka, A.H. (2014). Mozhlyvosti endovaskuliarnoho likuvannia aterosklerotychnoho urazhennia ekstrakranialnykh arterii u hostryi period ishemicnoho insultu [Possibilities of endovascular treatment of atherosclerotic lesions of extracranial arteries during acute period of ischemic stroke]. Naukovyi visnyk Uzhorodskoho universytetu.
8. Kurisu K. Carotid artery stenting in a patient with right-sided aortic arch with an aberrant left subclavian artery / K. Kurisu // Acta Neurochir (Wien). - 2011. - 153. - P. 2169 -2173.

9. Morasch M. D. Technique for subclavian to carotid transposition, tips, and tricks / M. D. Morasch // J vasc. Surg. - 2009. Vol. 49(1). - P. 251-254.
Seriia "Medytsyna" - Scientific Journal of Uzhhorod University. Series Medicine, 1(49), 144-149 [in Ukrainian].

5. Tanashyan, M.M. Lagoda, O.V., \& Gulevskaya, T.S. (2013). Progressiruyushchiy tserebralnyy ateroskleroz: klinicheskie, biokhimicheskie i morfologicheskie aspekty [Progressive cerebral atherosclerosis: clinical, biochemical and morphological aspects]. Ahaly klinicheskoy i eksperimentalnoy nevrologii - Annals of Clinical and Experimental Neurology, (4), 4-9 [in Russian].

6. Sihotský, V. (2016). Metodou prvej volby pri stenoze karotid je CEA. Cesk Slov Neurol., 79:112 (4)., 397-399.

7. Rodin, Yu.V., Simonyan, V.A., \& Dyuba, D.Sh. (2008). Operativnoe lechenie bolnykh s patologiey brakhiotsefalnykh arteriy sverhhvisokogo nevrologicheskogo riska [Operative treatment of patients with the pathology of brachiocephalic arteries of ultrahigh neurological risk]. Khirurgia Ukrainy - Surgery of Ukraine, 2 (4), 253-255 [in Russian].

8. Kurisu, K. (2011) Carotid artery stenting in a patient with right-sided aortic arch with an aberrant left subclavian artery. Acta Neurochir (Wien), 153, 2169-2173.

9. Morasch, M.D. (2009). Technique for subclavian to carotid transposition, tips, and tricks. J. Vasc. Surg., 49 (1), 251-254.

\section{I. KOPOLOVETS, M. FRANKOVICHOVA, P. BEREK, M. KUBIKOVA, P. O. BOLDIZHAR, V. V. RUSYN}

Clinic of Vascular Surgery, East Slovak Institute of Cardiovascular Diseases,

Pavol Jozef Šafárik University, Košice, Slovak Republic ${ }^{1}$

Uzhhorod National University ${ }^{2}$

\section{FEATURES OF SURGICAL TREATMENT OF PATIENTS WITH SUBCLAVIAN STEAL SYNDROME}

The aim of the work: to systematize the indications as well as to develop an algorithm for selection of patients with subclavian steal syndrome for surgical treatment.

Materials and Methods. The results of surgical treatment of 19 patients with subclavian steal syndrome were analyzed. All the patients were operated on when the possibilities of endovascular revascularization were exhausted. An arterial reconstruction was performed under general anaesthesia; transcranial oximetry was used to provide intraoperative neuromonitoring. Subclavian-carotid transposition (9 patients, $47.4 \%$ ) was chosen as the preferred method of arterial reconstruction. In addition to transposition, carotid-subclavian bypass ( 5 patients, $26.3 \%$ ), carotid-carotid bypass (4 patients, $21.1 \%$ ) and prosthetic repair of the brachiocephalic trunk (1 patient, $5.3 \%$ ) were applied.

Results and Discussion. Patients with upper limb ischemia, stage I (36.8 \%) and stage II (31.6 \%) prevailed in the study group. Among patients with upper limb ischemia, stage I, there were 4 (21.1\%) persons selected for stent-graft implantation with the coverage of the ostium of the left common carotid artery. Upper limb ischemia, stage IV was observed in 2 (10.5\%) patients. In the early postoperative period after carotid-carotid bypass, 1 (5.3\%) patient developed ischemic stroke. 1 (5.3\%) patient died after carotid-carotid bypass and stent-graft implantation. Tactics of treating patients with subclavian steal syndrome depends on the type of subclavian steal syndrome, the permeability state of the homo- and contralateral vessels responsible for the blood supply to the brain as well as the type of cerebrovascular disease.

Key words: carotid artery stenosis; subclavian steal syndrome; chronic cerebral ischemia; atherosclerosis. 
Клиника сосудистой хирургии, Восточно-Словацкий институт сердечно-сосудистых болезней, Университет П. И. Шасрарика, Медицинский фракультет, Кошице, Словакия ${ }^{1}$

Ужгородский национальный университет²

\section{ОСОБЕННОСТИ ХИРУРГИЧЕСКОГО .ЛЕЧЕНИЯ ПАЦИЕНТОВ С СИНДРОМОМ ПОДКЛЮЧИЧНО- ПОЗВОНОЧНОГО ОБКРАДЫВАНИЯ}

Цель работы: систематизировать показания и разработать алгоритм отбора пациентов с синдромом подключичнопозвоночного обкрадывания для хирургического лечения.

Материалы и методы. Проанализированы результаты хирургического лечения 19 больных с синдром подключичнопозвоночного обкрадывания (СПХО). Все больные были оперированы только после исчерпанных возможностей эндоваскулярной реваскуляризации. Артериальная реконструкция выполнялась под общим обезболиванием в условиях интраоперационного нейромониторинга с помощью транскраниальной оксиметрии. При выборе артериальной реконструкции предпочитали транспозицию подключичной артерии к общей сонной артерии (9 пациентов, 47,4 \%). Кроме транспозиции, у 5 пациентов (26,3 \%) выполняли сонно-подключичное шунтирование, у 4 пациентов (21,1 \%) сонно-сонное шунтирование, у одного пациента (5,3 \%) протезирование брахиоцефального ствола.

Результаты исследований и их обсуждение. В обследуемой группе преобладали пациенты с I (36,8 \%) и II (31,6 \%) степенью ишемии верхней конечности. К больным 1 степенем отнесены 4 пациента (21,1 \%), в которых запланирована имплантация стентграфта с закрытием устья левой ЗАГС. IV степень ишемии верхней конечности наблюдали у двух пациентов (10,5 \%). В раннем послеоперационном периоде у одного пациента (5,3 \%) после сонно-сонного шунтирования развился ишемический инсульт. Умер один больной (5,3 \%) после сонно-сонного шунтирования и имплантации стентграфта. Тактика лечения больных с СПХО зависит не только от вида СПХО, состояния проходимости гомо- и контрлатеральных сосудов, питающих головной мозг, но и от типа нарушения мозгового кровообращения.

Ключевые слова: стеноз сонных артерий; синдром подключично-позвоночного обкрадывания; хроническая ишемия головного мозга; атеросклероз. 